330.9

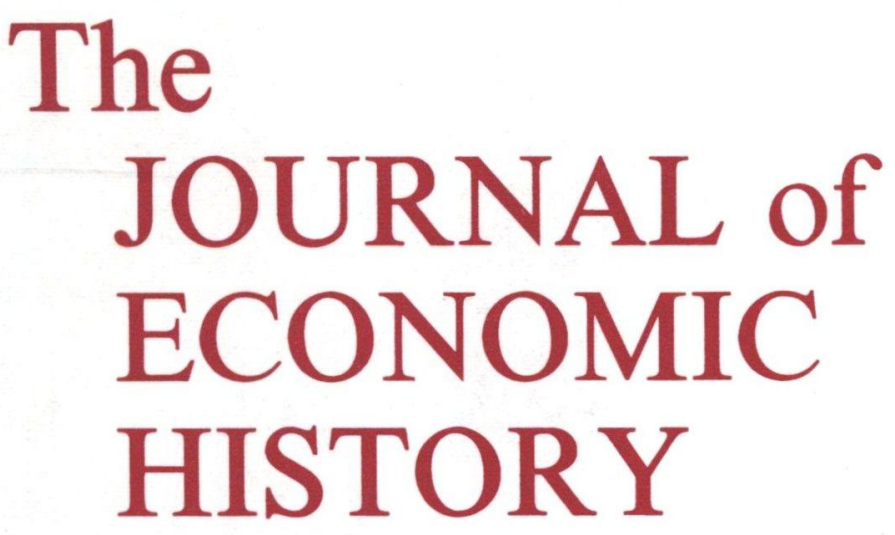

\title{
innovatio et traditio
}

Papers Presented at the Forty-First Annual MEETING of the ECONOMic History Association

MONEY, BANKS, AND REGULATIONS MARXIST APPROACHES TO ECONOMIC HISTORY LIBRARY VICTORIAN BRITAIN NEW STUDIES ON BRITISH IMPERIALISM ECONOMIC DEVELOPMENT OF EARLY MODERN EUROPE WOMEN'S EMPLOYMENT HISTORY CANADIAN AGRICULTURE DISSERTATION SUMMARIES 


\section{EDITORIAL STAFF}

Genevieve M. Gwynne, Assistant Editor

Ginalie Swaim, Assistant Editor

Richmond D. Williams, Business Manager

\begin{tabular}{ll}
\multicolumn{2}{c}{ EDITORIAL BOARD } \\
John H. Coatsworth & Chicago \\
Jan De Vries & Berkeley \\
Stanley L. Engerman & Rochester \\
David Felix & Washington University \\
Claudia D. Goldin & Pennsylvania \\
C. Knick Harley & Western Ontario \\
Ellis W. Hawley & Iowa \\
Robert Higgs & Washington, Seattle \\
Peter Lindert & California-Davis \\
Peter D. McClelland & Cornell \\
John P. McKay & Illinois \\
Richard W. Roehl & Michigan-Dearborn \\
Lars G. Sandberg & Ohio State \\
Richard C. Sutch & Berkeley \\
Peter Temin & MIT \\
Gavin Wright & Michigan \\
Kozo Yamamura & Washington, Seattle
\end{tabular}

The Journal of Economic History is published in March, June, September, and December by The Economic History Association at North Carolina State University. The Journal is sent to all members of the Association. Membership rates are: student membership, \$5.00; regular membership, United States, \$15.00; library subscriptions, \$25.00; regular membership, foreign $\$ 15.50$; professors emeriti who have been members of the Association for ten years, $\$ 10.00$; back issues, $\$ 5.00$. Applications and inquiries concerning membership and single copies should be addressed to Secretary-Treasurer Richmond D. Williams, Eleutherian Mills Historical Library, P.O. Box 3630, Wilmington, Delaware 19807.

Articles on economic history and related aspects of history or economics will be considered for publication by the editors. Those manuscripts incorporating the results of detailed original research should include some discussion of the broader significance of the subject matter. Contributions should be typed double-spaced; tables and footnotes, also double-spaced, should be grouped separately at the end of the paper. Three copies of each manuscript should be submitted, and each manuscript should be accompanied by a statement of the approximate number of words which it contains. A submission fee of $\$ 15.00$ is required from non-members of The Economic History Association. Prospective contributors may obtain from the Editoral Office a copy of "Suggestions to Contributors," a list of the major literary and stylistic customs of the Journal.

The Journal does not accept unsolicited book reviews, nor does it honor individuals' requests to review particular works. Reviews are indexed in the Book Review Index.

Manuscripts to be considered for publication in the JourNal should be directed to The Editors, Journal OF ECONOMIC History, Department of Economics and Business, North Carolina State University, Raleigh, NC 27650. Books for review should be sent to The Editors, Journal of Economic History, 215 Schaeffer Hall, University of Iowa, Iowa City, IA 52242.

\section{PUBLISHED QUARTERLY BY THE ECONOMIC HISTORY ASSOCIATION AT NORTH CAROLINA STATE UNIVERSITY}

BUSINESS OFFICE: ELEUTHERIAN MILLS HISTORICAL LIBRARY, P.O. BOX 3630, WILMINGTON, DELAWARE 19807

Second Class Postage Paid at Wilmington, Del. and at Additional Mailing Offices Copyright 1982 by The Economic History Association Printed in the U.S.A. by The William Byrd Press, Inc. ISSN 0022-0507 USPS-279580 


\section{THE JOURNAL \\ OF ECONOMIC HISTORY}

THE TASKS OF ECONOMIC HISTORY

Volume XLII

March 1982

Number 1

\section{PAPERS PRESENTED AT THE FORTY-FIRST ANNUAL MEETING OF THE ECONOMIC HISTORY ASSOCIATION}

JoNATHAN HUGHES

The Great Strike at Nushagak Station, 1951: Institutional Gridlock

RICHARD SyLla

Monetary Innovation in America

Discussion: Michael David Bordo

Eugene Nelson White

The Political Economy of Banking Regulation, 1864-1933

Discussion: Richard H. KeEHN

ROBERT B. ZEVIN

The Economics of Normalcy

Stephen Resnick and Richard WolfF

A Reformulation of.Marxian Theory and Historical Analysis

Susan Feiner

Factors, Bankers, and Masters: Class Relations in the Antebellum South

ROLF JENSEN

The Transition from Primitive Communism: The Wolof Social Formation of West Africa

Rona S. WeIsS

Primitive Accumulation in the United States: The Interaction between Capitalist and Noncapitalist Class Relations in Seventeenth-Century Massachusetts

Discussion: William LazonicK

BARRY J. EICHENGREEN

The Proximate Determinants of Domestic Investment in Victorian Britain

William H. Phillips

Induced Innovation and Economic Performance in Late Victorian British Industry 
William P. KenNedy

Economic Growth and Structural Change in the United Kingdom, 18701914

Discussion: Ben BaACK; Donald N. McCloskey

Lance E. Davis and Robert Huttenback

The Political Economy of British Imperialism: Measures of Benefits and Support

Discussion: Michael Edelstein

B. R. TOMLINSON

The Political Economy of the Raj: The Decline of Colonialism

DENNIS O. FLYNN

Fiscal Crisis and the Decline of Spain (Castile)

Michael R. Weisser

The Agrarian Depression in Seventeenth-Century Spain

Philip T. HofFman

Sharecropping and Investment in Agriculture in Early Modern France

Discussion: Carla Rahn Phillips; Domenico Sella

Susan B. Carter and Mark Prus

The Labor Market and the American High School Girl, 1890-1928

Susan A. Matthies

Families At Work: An Analysis By Sex Of Child Workers in the Cotton Textile Industry

Peter Philips

Gender-Based Wage Differentials in Pennsylvania and New Jersey Manufacturing, 1900-1950

Discussion: Robert A. MARgo

MARVIN MCINNIS

The Changing Structure of Canadian Agriculture, 1867-1897

Trevor J. O. Dick

Mechanization and North American Prairie Farm Costs 1896-1930

Robert E. ANKLi ANd Wendy Millar

Ontario Agriculture in Transition: The Switch from Wheat to Cheese

Discussion: WAYNE D. RASMUSSEN

\section{SUMMARIES OF DOCTORAL DISSERTATIONS}

JAMES W. EATON

The Wyoming Stock Growers Association: An Application of Davis's and North's Theory of Institutional Change 
Cathy Louise McHugh

The Family Labor System in the Southern Cotton Textile Industry, 18801915

Roberto B. Martins

Growing in Silence: The Slave Economy of Nineteenth-Century Minas Gerais, Brazil

ROBERT G. MOELLER

Peasants, Politics, and Pressure Groups in War and Inflation: A Study of the Rhineland and Westphalia, 1919-1924

LON L. Peters

Cooperative Competition in German Coal and Steel, 1893-1914

Arthur G. WoOlf

Energy and Technology in American Manufacturing: 1900-1929

\section{WORKSHOP SUMMARY}

David Feeny, Convenor

Quantitative Third-World Economic History

EDITORS' NOTES

\section{REVIEWS OF BOOKS}

\section{MEDIEVAL}

ROWLEY. Origins of Open-Field Agriculture

C. J. Dahlman

239

\section{MODERN EUROPE}

hausman. Public Policy and Supply of Coal to London PAYNE. Early Scottish Limited Companies WIENER. English Culture and Decline of Industrial Spirit KIRBY. Decline of British Economic Power since 1870 MOMMSEN, Ed. Emergence of Welfare State in Britain and Germany

WILliams. From Pauperism to Poverty

MILLER. The Bon Marché

KUISEL. Capitalism and State in Modern France

HAUMANN. Kapitalismus im zaristischen Staat

C. K. Hyde 240

M. Edelstein 241

D. H. Aldcroft 243

D. H. Aldcroft 243

K. de Schweinitz 244

K. de Schweinitz 244

R. Geiger 245

C. P. Kindleberger 247

M. C. Spechler 248

ASIA

MURRAY. Capitalism in Colonial Indochina

T. Smith 249

UNITED STATES

HUTCHINSON. Legislative History of American Immigration

Policy

S. Engerman 251

hershberg, Ed. Philadelphia

D. Lindstrom 251 
GREENBERG. Financiers and Railroads, 1869-1889

G. T. Mills 253

wooD. Kansas Beef Industry

M. A. Yeager 254

HAWLEY, Ed. Herbert Hoover as Secretary of Commerce

S. Engelbourg 257

ROSE. Energy Transition and the Local Economy

A. G. Woolf 258

BESS and FARRIS. U.S. Maritime Policy

C. K. Harley 259

\section{ECONOMIC THOUGHT AND DOCTRINE}

HILFERDING. Finance Capital

R. Cameron

259

\section{GENERAL AND MISCELLANEOUS}

JASTRAM. Silver: The Restless Metal

LITTLETON. Accounting Evolution to 1900

J. J. McCusker 260

ANDERSON. Regulatory Politics and Electric Utilities

H. T. Johnson 261

STONE. The Past and the Present

A. R. Sanderson 262

BOSERUP. Population and Technological Change

C. Tilly 263

W. W. Rostow 265 